\title{
Varieties of Corporate Social Responsibility (CSR): An Analysis of Prominent Definitions of CSR in Korea ${ }^{*}$
}

\author{
HANNAH JUN**
}

Continued interest in corporate social responsibility (CSR) has led to a plethora of definitions, standards, and guidelines. While this has contributed to a rich and diverse body of literature, there is a pressing need for clarity on what CSR means in specific geographic contexts and how these reflect stakeholder expectations. This is particularly the case for firms, which are the objects of CSR evaluations and investment by socially responsible investors. To enhance an understanding of the global varieties of CSR, this paper analyzes prominent definitions of CSR in Korea, specifically those proposed by the Korea Economic Justice Institute (KEJI) and Sustinvest Co., Ltd. By doing so, this paper will help articulate how CSR is conceptualized in Korea and how to situate this variety of CSR in a comparative context.

Keywords: Corporate Social Responsibility (CSR), Korea, Korea Economic Justice Institute (KEJI), Sustinvest, Varieties of CSR

* This work was supported by Hankuk University of Foreign Studies Research Fund of 2014.

${ }^{* *}$ Assistant Professor, Hankuk University of Foreign Studies;

E-mail: jun.hannah@gmail.com 


\section{INTRODUCTION}

The growing impact of firms on a broad range of issues has led to efforts to define the proper role of firms in society. Specifically, this has contributed to a debate on what constitutes the broader responsibilities of firms, namely, corporate social responsibility (CSR).

After several decades of scholarly research, CSR remains a contested concept (e.g., Matten and Moon 2008). Most definitions of CSR allude to responsibilities that go beyond purely economic ones, and within the literature, two strands have come to the fore. One group of studies suggests a growing convergence of CSR in light of global initiatives, a globalization of firm operations, and a belief in shared values particularly among the largest firms and markets (e.g., Misani 2010). However, a second group argues that while there has been some mainstreaming in CSR jargon and terminology, there are clear national and/or regional varieties of CSR that demand proper articulation (Jamali and Mirshak 2007; Visser 2006, 2008). This latter approach is particularly useful in understanding the social, cultural, and institutional underpinnings of how CSR is understood in specific geographic contexts.

Aside from the importance of defining CSR in the literature, how CSR is defined has significant practical implications. This is especially the case for firms that desire to operate in a more socially responsible way, as they look to CSR definitions for guidance. Because there are a variety of global initiatives as well as local expectations (particularly for an emerging economy such as Korea), this may further confuse firms when it comes to planning, implementing, and monitoring CSR strategies and frameworks. In addition, because firms are increasingly the targets of evaluation, how CSR is defined has a direct impact on a firm's CSR evaluations and rankings. In turn, these rankings may play a significant role in investment strategies for socially responsible investors, suggesting that firms have even greater incentive to project a more responsible corporate image (Jun 2013).

As such, this paper seeks to address this gap in literature by articulating how CSR is conceptualized in Korea. To do so, this paper first presents relevant literature regarding the debate on the general applicability of CSR definitions and frameworks. In particular, the review highlights Carroll's (1991) pyramid of corporate social responsibility, one of the most popular frameworks used in defining CSR, vis-à-vis the analysis by Visser (2006) on the pyramid's applicability in explaining CSR in African economies. This paper then provides a section on data selection and proceeds with an analysis of two institutional definitions of CSR in Korea. These include CSR definitions proposed by the Korea Economic Justice Institute (KEJI) and Sustinvest Co., Ltd., two of the most prominent CSR-related research institutions in Korea. Lastly, this paper places the Korean conceptualization of CSR in a comparative context and offers concluding remarks. 


\section{LITERATURE REVIEW}

Within the debate on varieties of CSR, one group of studies suggests a growing convergence around the concept of global CSR. This is because international standardization and reporting seem to reflect a broad alignment of core issues and values. For example, Misani (2010) argues that socially responsible firms appear to converge on a set of CSR standards rather than striving for differentiation, as they face pressures to "conform" rather than pressures to "perform" (Barreto and Baden-Fuller 2006). Reasons for this include herd behavior, institutional isomorphism, and strategic cooperation.

With regards to defining CSR, the pyramid of corporate social responsibilities proposed by Carroll (1991) remains one of the most popular. At its core, the model suggests that CSR encompasses economic, legal, ethical, and discretionary (or philanthropic) responsibilities. The model not only argues that those four factors encompass socially responsible behavior but also that economic responsibilities constitute the most important responsibilities of a firm, followed by legal, ethical, and discretionary ones (hence the pyramid structure). This conceptualization has been particularly popular among managers, who appreciate the emphasis on economic responsibilities as forming the foundation - or even raison d'être - of a firm's function in society.

Despite the model's clarity and popularity, there have been observations about its bias in reflecting the type of shareholder capitalism popular in the AngloAmerican tradition. This is because shareholder capitalism emphasizes the role of managers in maximizing shareholder profits (or value), and a focus on corporate economic responsibilities is consistent with this emphasis. Although few scholars would go so far as to argue that economic responsibilities are not important, several (e.g., Jamali and Mirshak 2007; Visser 2006, 2008) argue that social agendas are still largely driven by local culture, expectations, and priorities. Thus, at the very least, we may expect differences in the types of responsibilities firms are expected to address and their relative importance in the larger scheme of things.

One well-cited response to Carroll's (1991) pyramid of corporate social responsibilities is the pyramid of CSR for African economies offered by Visser (2006). Visser (2006) argues that the original model is less relevant in developing economies and has weaker descriptive power because relative priorities of CSR are often different from the shareholder-centric ordering. He goes on to argue that not only are the order of priorities different (with the pyramid emphasizing economic, philanthropic, legal, and ethical responsibilities, in that order, due to longstanding traditions of corporate philanthropy, gaps in the rule of law, and a history of receiving financial aid), but also that individual responsibilities reflect overtones different from the original model. For example, Visser (2006) suggests that economic responsibilities in the original model generally refer to profit creation, 
while in many developing economies, this also encompasses job creation.

As such, there are various views in the academic discourse about the convergence of global CSR. In explaining reasons behind divergences in CSR practices and conceptualizations, Blowfield and Frynas (2005) argue that issues such as stakeholder engagement present challenges in developing countries where language, culture, education, and pluralistic values may affect the negotiation and decisionmaking processes. In addition, Chen and Bouvain (2009), in their study on corporate social reporting in the US, UK, Austria, and Germany, suggest that while membership in the United Nations Global Compact (UNGC), a voluntary and strategic initiative aimed at businesses committed to aligning corporate strategy and ten universally accepted principles, has had an effect in environmental and labor-related reporting, firms from different countries vary significantly regarding CSR promotion and emphasis.

Further studies, such as that by Jamali and Neville (2011), go further to suggest patterns of crossvergence (i.e., convergence and divergence) that reflect a hybridized expression of CSR in developing countries. The study argues that although there may be a cosmetic level of convergence in explicit CSR (e.g., Matten and Moon 2008), a country's multi-layered institutional framework lends itself to meaningful differences.

Given evidence supporting varied forms of CSR, efforts have been made to explore the meaning and practice of CSR over a wide range of geographic contexts. This is especially important for firms looking to conduct operations overseas, as they may benefit from an understanding of cultural expectations and greater acceptance by the local community. For example, Chapple and Moon (2005) find that multinational corporations (MNCs) appear to conform to respective national profiles rather than imposing a profile of CSR on their host countries. This supports the view that differences in national business systems can explain divergences in the conceptualization and practice of CSR.

In addition to the task of understanding national varieties of CSR, firms face another challenge in that there are a variety of international standards and guidelines with respect to CSR reporting (Table 1). While the focus of this paper is to understand the conceptualization of CSR with respect to definitions proposed by major institutions in Korea, future research may also explore the interplay between international CSR guidelines and national priorities.

\section{DATA SELECTION}

There are several groups of stakeholders that provide definitions on what constitutes the social responsibilities of firms. In Korea, these include not only CSR-related research institutions, but also government-related agencies, firms, industrial associations and unions, as well as civil society groups. Given the breadth 


\section{TABLE 1. SUMMARY OF KEY INTERNATIONAL GUIDELINES AND STANDARDS} REGARDING CSR

\begin{tabular}{|c|c|c|}
\hline $\begin{array}{c}\text { International } \\
\text { Standard }\end{array}$ & Inception & Description \\
\hline $\begin{array}{l}\text { OECD Guidelines } \\
\text { for Multinational } \\
\text { Enterprises }\end{array}$ & 1976 & $\begin{array}{l}\text { Enterprises should: contribute to economic, environmental } \\
\text { and social progress with a view to achieving sustainable } \\
\text { development, respect internationally recognized human } \\
\text { rights, encourage local capacity building through close co- } \\
\text { operation with the local community, encourage human } \\
\text { capital formation, support and uphold good corporate } \\
\text { governance principles, engage with relevant stakeholders, } \\
\text { abstain from any improper involvement in local political } \\
\text { activities (excerpt) }\end{array}$ \\
\hline ISO 14001 & 1996 & $\begin{array}{l}\text { Sets out criteria for an environmental management system. } \\
\text { It does not state requirements for environmental perfor- } \\
\text { mance, but maps out a framework that a company or orga- } \\
\text { nization can follow to set up an effective environmental } \\
\text { management system. }\end{array}$ \\
\hline $\begin{array}{l}\text { Global Reporting } \\
\text { Initiative (GRI) }\end{array}$ & 2000 & $\begin{array}{l}\text { Categories in the "G4 Sustainability Reporting Guidelines" } \\
\text { include: economic, environmental, labor practices and de- } \\
\text { cent work, human rights, society, and product responsibility }\end{array}$ \\
\hline UN Global Compact & 2000 & $\begin{array}{l}\text { Encompasses ten principles in the areas of human rights, } \\
\text { labor, the environment and anti-corruption based on The } \\
\text { Universal Declaration of Human Rights, The International } \\
\text { Labour Organization's Declaration on Fundamental Princi- } \\
\text { ples and Rights at Work, The Rio Declaration on Environ- } \\
\text { ment and Development, and The United Nations Conven- } \\
\text { tion Against Corruption }\end{array}$ \\
\hline Equator Principles & 2003 & $\begin{array}{l}\text { A risk management framework, adopted by financial ins- } \\
\text { titutions, for determining, assessing and managing envi- } \\
\text { ronmental and social risk in projects and is primarily } \\
\text { intended to provide a minimum standard for due diligence } \\
\text { to support responsible risk decision-making }\end{array}$ \\
\hline $\begin{array}{l}\text { AA1000S } \\
\text { (AccountAbility } \\
\text { Principles Standard) }\end{array}$ & 2008 & $\begin{array}{l}\text { Demands that an organization actively engages with its } \\
\text { stakeholders, fully identifies and understands the sustain- } \\
\text { ability issues that will have an impact on its performance, } \\
\text { and then uses this understanding to develop responsible } \\
\text { business strategies and performance objectives }\end{array}$ \\
\hline ISO 26000 & 2010 & $\begin{array}{l}\text { Social responsibility consists of seven core subjects: go- } \\
\text { vernance, human rights, labor practices, the environment, } \\
\text { fair operating practices, consumer issues, and community } \\
\text { involvement and development }\end{array}$ \\
\hline
\end{tabular}

of sources in light of the paper's more limited scope, this paper narrows the investigation to definitions from prominent CSR-related institutions. Part of the justification for choosing CSR-related institutions is that these institutions provide quantitative and qualitative evaluations of firms' CSR performance. This means that at least on surface, these institutions are tasked with generating objective evaluation criteria that reflect a broad range of local expectations regarding CSR. 
Because scores and rankings are formulated, often made publicly available, and may be used by socially responsible investors in making investment decisions, firms often use these criteria as guidance to generate and execute CSR strategies.

Of the major CSR-related research institutions, a brief sample includes SRIrelated research institutions such as the Center for Good Corporate Governance (CGCG), Eco-Frontier, Korea Corporate Governance Service (KCGS), Korea CSR Research Service, SolAbility Co., Ltd., and Sustinvest Co., Ltd. These research institutions are also significant in that they are all signatories of the UN-backed Principles of Responsible Investment (PRI). Of these institutions, Korea CSR Research Service, SolAbility, and Sustinvest have traditionally engaged in a comprehensive analysis of corporate responsibilities with respect to the environment, social issues, and governance considerations, and as evaluation criteria are only made publicly available for Sustinvest, this institutional definition was a primary candidate for consideration.

In addition, the use of data in academic research was an important factor in choosing institutional definitions for the analysis. In addition to Sustinvest, data provided by the Korea Economic Justice Institute (KEJI) has also been featured in academic research involved in measuring CSR performance of local firms (e.g., Choi et al. 2010; Oh et al. 2011). In addition, evaluation criteria and weightings are publicly available, which would be of use to firms, investors, as well as scholars in the field.

This paper does not claim to provide an exhaustive analysis of all meaningful definitions of CSR in Korea. Rather, it aims to undertake an in-depth investigation of two definitions used prominently in the literature and in practice, namely those provided by KEJI and Sustinvest.

\section{KOREA ECONOMIC JUSTICE INSTITUTE (KEJI)}

\section{Background}

By the late 1980s, there were increased calls by the public for greater business accountability largely due to greater public participation following democratic elections in 1987 (Nam and Jun, 2011). One prominent move was the establishment of the Citizens' Coalition for Economic Justice (CCEJ) in 1989. At the outset, the CCEJ's goals included the promotion of economic justice, protection of the environment, and democratic and social development. It was against this backdrop that Korea's first comprehensive CSR index was developed with the founding of the Korea Economic Justice Institute (KEJI) in 1991.

\section{Evaluation Criteria}

The KEJI index assesses corporate performance with regards to seven factors 
out of a total 75 points. The first is soundness (20 out of 75 points), which refers to shareholder composition, investment, and financing. The second factor evaluated is fairness (11 out of 75 points). This encompasses issues such as fair trade, economic concentration, transparency, and supplier relationships. The third factor is contribution to society ( 7 out of 75 points), which includes care for minority groups and corporate philanthropy. The fourth factor is consumer protection ( 7 out of 75 points), an area that has become more visible particularly since the $1980 \mathrm{~s}$. Consumer protection includes consumer rights, product quality, and promotion. The fifth factor is environmental protection (10 out of 75 points), with issues including efforts to improve the environment, environmental friendliness, and overall compliance with environmental regulations. The sixth factor is employee satisfaction (10 out of 75 points). Employee satisfaction considers workplace safety, investment in human resources, wages and welfare, labor-management relationships, as well as gender equality. Lastly, the seventh item is contribution to the economy (10 out of 75 points). This includes an evaluation of the firm's research and development (R\&D) efforts, operating performance, and economic contribution with regards to tax payments, productivity growth, and exports.

TABLE 2. KEJI EVALUATION CRITERIA

\begin{tabular}{lcl}
\hline \multicolumn{1}{c}{ Factor } & Portion (\%) & \multicolumn{1}{c}{ Description } \\
\hline Soundness & $27 \%(20 / 75)$ & shareholder composition, investment, and financing \\
\hline Fairness & $15 \%(11 / 75)$ & $\begin{array}{l}\text { fair trade, economic concentration, transparency, } \\
\text { supplier relationships }\end{array}$ \\
\hline Contribution to Society & $9 \%(7 / 75)$ & care for minority groups, corporate philanthropy \\
\hline Consumer Protection & $9 \%(7 / 75)$ & consumer rights, product quality, promotion \\
\hline Environmental Protection & $13 \%(10 / 75)$ & $\begin{array}{l}\text { efforts to improve the environment, environmental } \\
\text { friendliness, compliance with environmental } \\
\text { regulations }\end{array}$ \\
\hline Employee Satisfaction & $13 \%(10 / 75)$ & $\begin{array}{l}\text { workplace safety, investment in human resources, } \\
\text { wages and welfare, labor-management relationships, } \\
\text { gender equality }\end{array}$ \\
\hline Economic Contribution & $13 \%(10 / 75)$ & $\begin{array}{l}\text { R\&D efforts, operating performance, economic } \\
\text { contribution (tax payments, productivity growth, } \\
\text { exports) }\end{array}$ \\
\hline
\end{tabular}

SOURCE: Korea Economic Justice Institute.

From this multi-faceted definition, we can infer that the concept of CSR encompasses issues of corporate governance (factors one and two), philanthropy and economic responsibilities (factors three and seven), responsiveness to stakeholder demands and needs (factors four and six), and environmental responsibilities (factor five) (Oh et al. 2011). With regards to overall weighting, corporate governance issues account for $41 \%$ of the total evaluation, $23 \%$ for economic responsibilities and philanthropy, $23 \%$ for responsiveness to stakeholder demands 
and needs, and $13 \%$ for environmental responsibilities.

At first glance, there seems to be an emphasis on legal and ethical responsibilities when placing KEJI's composition of CSR within the pyramid of corporate social responsibilities. This has to do with the emphasis on corporate governance ( $41 \%$ of the total score), responsiveness to stakeholder demands and needs $(23 \%)$, and environmental responsibilities (13\%), which may seem pertain more to the realm of law and ethics than to a purely economic realm. At the same time, the importance of the economic function of firms cannot be ignored. In terms of percentages, economic responsibilities are relatively lower at $23 \%$ (of which $9 \%$ refers to contribution to society via philanthropic activities). However, it can be argued that because the focus of the KEJI index is to gauge "justice" in the process of a firms' economic activities, it is difficult to translate this index with the original pyramid of corporate social responsibilities. In light of this, this paper further examines the definition of CSR offered by Sustinvest Co., Ltd.

\section{SUSTINVEST CO., LTD.}

\section{Background}

Sustinvest Co., Ltd. (hereafter, "Sustinvest") is an independent think tank that was founded in 2006 with the purpose evaluating and analyzing corporate performance regarding environmental, social, and governance (ESG) issues. In addition to conducting annual CSR evaluations, Sustinvest offers advisory services for institutional investors looking to integrate socially responsible firms in investment portfolios, funds, and indexes.

\section{Evaluation Criteria}

The evaluations conducted by Sustinvest assess corporate performance with respect to environmental, social, and governance issues. This categorization reflects a focus on providing services for socially responsible investors, the latter of whom may make investment decisions based on performance with regards to environmental, social, and/or governance issues in a particular market. Given that many categories and performance indicators overlap, Sustinvest offers evaluation criteria based on specific items in the value chain. As such, the evaluation covers management infrastructure, safety management, innovation, production process, supply chain management, marketing/customer support, social contributions/local community investment, and corporate governance. Following the evaluation, Sustinvest generates individual scores for environmental performance, social performance, and governance performance, as well as a comprehensive score that incorporates all three areas. 
Table 3. Sustinvest (ESGValue ${ }^{\text {TM }}$ ) EValuation Criteria

\begin{tabular}{|c|c|c|c|}
\hline Value Chain & ESG & Category & Key Performance Indicators (KPIs) \\
\hline \multirow[t]{2}{*}{$\begin{array}{l}\text { Management } \\
\text { Infrastructure }\end{array}$} & $\mathrm{E}, \mathrm{S}$ & $\begin{array}{l}\text { sustainability } \\
\text { management } \\
\text { system }\end{array}$ & $\begin{array}{l}\text { CEO intent } \\
\text { sustainability strategy and goals } \\
\text { strategic framework for sustainability } \\
\text { disclosure of sustainability management } \\
\text { stakeholder communication }\end{array}$ \\
\hline & $\mathrm{E}, \mathrm{S}$ & ethical management & $\begin{array}{l}\text { ethical codes/training/monitoring system } \\
\text { adherence to the law }\end{array}$ \\
\hline \multirow{6}{*}{$\begin{array}{l}\text { Safety } \\
\text { Management }\end{array}$} & \multirow{6}{*}{$\mathrm{S}$} & job security & resources for re-employment, training \\
\hline & & $\begin{array}{l}\text { human resource } \\
\text { development, training }\end{array}$ & $\begin{array}{l}\text { capability development programs } \\
\text { CSR performance evaluation, wage } \\
\text { structure }\end{array}$ \\
\hline & & $\begin{array}{l}\text { equal employment } \\
\text { opportunities, diversity }\end{array}$ & $\begin{array}{l}\text { anti-discriminatory policies } \\
\text { employee gender ratio, wage ratio }\end{array}$ \\
\hline & & $\begin{array}{l}\text { working conditions, } \\
\text { working environment }\end{array}$ & $\begin{array}{l}\text { work-life balance programs } \\
\text { health and morale improvement programs }\end{array}$ \\
\hline & & $\begin{array}{l}\text { labor-management } \\
\text { relations, harmony }\end{array}$ & $\begin{array}{l}\text { negotiation programs } \\
\text { labor dispute cases } \\
\text { labor-management relations programs }\end{array}$ \\
\hline & & $\begin{array}{l}\text { employee health and } \\
\text { safety }\end{array}$ & $\begin{array}{l}\text { health security polices/system/training } \\
\text { industrial accident cases } \\
\text { level of accident prevention schemes }\end{array}$ \\
\hline \multirow{4}{*}{ Innovation } & $\mathrm{E}, \mathrm{S}$ & innovative capabilities & $\begin{array}{l}\text { increases in R\&D } \\
\text { development and investment in sustainable } \\
\text { technologies/products/services } \\
\text { industrial pollution improvement systems }\end{array}$ \\
\hline & $\mathrm{E}, \mathrm{S}$ & $\begin{array}{l}\text { organizational/process/ } \\
\text { product innovation }\end{array}$ & $\begin{array}{l}\text { improvement in raw material/use/disposal } \\
\text { stages and packaging } \\
\text { culture of promoting innovation }\end{array}$ \\
\hline & $\mathrm{E}$ & $\begin{array}{l}\text { addressing climate } \\
\text { change }\end{array}$ & $\begin{array}{l}\text { improvement in product energy efficiency } \\
\text { and greenhouse gas emissions } \\
\text { new businesses dealing with climate } \\
\text { change }\end{array}$ \\
\hline & $\mathrm{S}$ & $\begin{array}{l}\text { intellectual property } \\
\text { rights disputes }\end{array}$ & $\begin{array}{l}\text { instances intellectual property rights } \\
\text { disputes and resolution }\end{array}$ \\
\hline \multirow{4}{*}{$\begin{array}{l}\text { Production } \\
\text { Process }\end{array}$} & \multirow{4}{*}{$\mathrm{E}$} & distribution and transport & $\begin{array}{l}\text { efforts to reduce environment load during } \\
\text { shipping and distribution }\end{array}$ \\
\hline & & $\begin{array}{l}\text { input materials } \\
\text { management }\end{array}$ & $\begin{array}{l}\text { improvement in resource productivity } \\
\text { energy productivity/water use reduction } \\
\text { reduction of chemical substances }\end{array}$ \\
\hline & & emissions management & $\begin{array}{l}\text { water pollution/air pollution management } \\
\text { waste disposal management } \\
\text { environmental accident prevention plan }\end{array}$ \\
\hline & & $\begin{array}{l}\text { greenhouse gas } \\
\text { management }\end{array}$ & $\begin{array}{l}\text { greenhouse gas emission reduction and } \\
\text { performance }\end{array}$ \\
\hline
\end{tabular}




\begin{tabular}{|c|c|c|c|}
\hline Value Chain & ESG & Category & Key Performance Indicators (KPIs) \\
\hline \multirow{4}{*}{$\begin{array}{l}\text { Supply Chain } \\
\text { Management }\end{array}$} & $\mathrm{S}$ & $\begin{array}{l}\text { fair trade programs, } \\
\text { transaction transparency } \\
\text { and monitoring }\end{array}$ & $\begin{array}{l}\text { policies guiding vendor selection } \\
\text { fair trade training and management } \\
\text { systems reporting/monitoring systems for } \\
\text { unfair transactions cases of unfair } \\
\text { transactions }\end{array}$ \\
\hline & $\mathrm{E}$ & green purchasing & green purchasing programs \\
\hline & $\mathrm{E}, \mathrm{S}$ & $\begin{array}{l}\text { evaluation of social/ } \\
\text { environmental } \\
\text { performance of vendors }\end{array}$ & $\begin{array}{l}\text { reflection of social/environmental } \\
\text { performance indicators in vendor selection }\end{array}$ \\
\hline & $\mathrm{S}$ & $\begin{array}{l}\text { win-win cooperation } \\
\text { programs }\end{array}$ & $\begin{array}{l}\text { technology cooperation, financial support, } \\
\text { training programs, marketing assistance for } \\
\text { vendors }\end{array}$ \\
\hline \multirow{4}{*}{$\begin{array}{l}\text { Marketing, } \\
\text { Customer } \\
\text { Support }\end{array}$} & $\mathrm{S}$ & fair marketing & unjustified displays or false advertising \\
\hline & $\mathrm{S}$ & $\begin{array}{l}\text { customer information } \\
\text { protection }\end{array}$ & $\begin{array}{l}\text { customer information protection policies/ } \\
\text { task force/system cases of customer } \\
\text { information leakage }\end{array}$ \\
\hline & $\mathrm{S}$ & $\begin{array}{l}\text { customer satisfaction } \\
\text { management }\end{array}$ & $\begin{array}{l}\text { consumer complaints management system } \\
\text { (CCMS) certification cases of product } \\
\text { recalls notice of product warnings and } \\
\text { proper use }\end{array}$ \\
\hline & $\mathrm{E}$ & green marketing & $\begin{array}{l}\text { advertising environmental friendliness of } \\
\text { products customer behavior program }\end{array}$ \\
\hline \multirow{4}{*}{$\begin{array}{l}\text { Social } \\
\text { Contributions and } \\
\text { Local Community } \\
\text { Investment }\end{array}$} & $\mathrm{S}$ & fair competition & violations of fair competition/monopoly \\
\hline & $\mathrm{E}, \mathrm{S}$ & $\begin{array}{l}\text { participation in } \\
\text { global initiatives }\end{array}$ & $\begin{array}{l}\text { membership in global initiatives and } \\
\text { activities }\end{array}$ \\
\hline & $\mathrm{E}, \mathrm{S}$ & social contribution & $\begin{array}{l}\text { social contribution programs/donations } \\
\text { stakeholder participation in program } \\
\text { planning }\end{array}$ \\
\hline & $\mathrm{S}$ & $\begin{array}{l}\text { investment in local } \\
\text { community }\end{array}$ & $\begin{array}{l}\text { community development programs } \\
\text { community participation process } \\
\text { cases of conflict or violation of human } \\
\text { rights regarding local communities }\end{array}$ \\
\hline \multirow{5}{*}{$\begin{array}{l}\text { Corporate } \\
\text { Governance }\end{array}$} & \multirow{5}{*}{ G } & shareholder rights & $\begin{array}{l}\text { protection of controlling management/ } \\
\text { minority shareholders/dividend payout } \\
\text { proper notice of general shareholders' } \\
\text { meeting }\end{array}$ \\
\hline & & Transparency & $\begin{array}{l}\text { violations of public notice/internal } \\
\text { transactions/ accounting standards } \\
\text { investor relations (IR) implementation }\end{array}$ \\
\hline & & $\begin{array}{l}\text { board of directors } \\
\text { structure and } \\
\text { management }\end{array}$ & $\begin{array}{l}\text { separation of CEO and board chairman } \\
\text { audit committee/independent directors } \\
\text { selection process for independent directors } \\
\text { sustainability committee at the board level }\end{array}$ \\
\hline & & $\begin{array}{l}\text { executive } \\
\text { compensation }\end{array}$ & $\begin{array}{l}\text { compensation pegged to firm performance } \\
\text { gap between executive and managerial } \\
\text { compensation } \\
\text { compensation committee }\end{array}$ \\
\hline & & affiliates risk & $\begin{array}{l}\text { contingent liabilities risk } \\
\text { transaction portion of affiliates/related } \\
\text { persons }\end{array}$ \\
\hline
\end{tabular}

SOURCE: Sustinvest, translated by author. 
Areas that are included in Sustinvest's evaluation and that are absent in the KEJI index include innovation. On the one hand, specific items within the category such as innovative capabilities, organizational/process/product innovation, and intellectual property rights disputes are unique to Sustinvest's evaluation, while addressing climate change is a shared feature of both indexes. While weightings for each factor are not made public, environmental and social issues are more integrated with all but one of the items in the value chain, while there is a separate evaluation specifically for corporate governance. This may suggest some differrences in focus between the KEJI index and that provided by Sustinvest.

Interestingly, Sustinvest does not have a separate section within the evaluation matrix devoted to a firm's economic performance. This is not because financial performance is unimportant. Rather, Sustinvest focuses on ESG performance issues as their clients, professional SRI investors, seek investment advice on the basis of ESG performance rather than just on the basis of financial considerations.

\section{DISCUSSION}

Both KEJI and Sustinvest offer insight into the conceptualization and expected practice of CSR in Korea. It is difficult to gauge the relative importance of responsibilities as found in the pyramid of corporate social responsibilities (although KEJI provides a publicly-available weighted evaluation). However, the foursegment, pyramid framework does allow for local CSR definitions to inform the understanding of economic, legal, ethical, and discretionary responsibilities as understood in the local context. In other words, the classification of responsibilities in the original pyramid does not necessarily impose a normative definition, as can be seen in the respective analyses by Carroll (1991) and Visser (2006).

As such, the following section fleshes out how the four responsibilities (i.e., economic, legal, ethical, discretionary) are understood in Korea based on the two aforementioned definitions.

\section{Economic Responsibilities}

According to the KEJI index, a firm's economic responsibilities include R\&D efforts, operating performance, and economic contribution in the form of tax payments, productivity growth, and exports. While the CSR matrix proposed by Sustinvest does not explicitly evaluate corporate economic performance, this has more to do with the nature of Sustinvest's evaluations (i.e., ESG performance) rather than suggesting unimportance of the financial performance of firms. The conceptualization of economic responsibilities in Korea in-line with KEJI's index is relatively closer to the broader definition suggested by Visser (2006) rather than to the narrower one offered by Carroll (1991). Given Korea's export-oriented 
economy and drive to improve the higher-tech IT industry, Korea's definition understandably includes considerations of $\mathrm{R} \& \mathrm{D}$, productivity growth, and exports.

\section{Legal Responsibilities}

The importance of legal responsibilities of firms is interwoven in the two definitions of Korean CSR. This includes adherence to the law with regards to fair trade, supplier relationships, workplace safety, and environmental regulations. In light of social issues such as human rights and quality of employment, the government (in particular, the Ministry of Employment and Labor) has maintained regulatory objectives encompassing issues such as industrial relations, labor standards, occupational safety and health, employment and employment services, vocational training and skills development, as well as equal employment. In addition, cognizance of environmental regulations can be traced to the country's legislative history, with current regulations encompassing environmental pollution, biodiversity conservation, waste control, toxic and hazardous substances, and water supply. As such, it is not surprising to find these legal responsibilities addressed in the CSR definitions for both KEJI and Sustinvest.

Legal responsibilities also extend to some governance issues, such as shareholder rights, transparency and accountability, structure of boards of directors, and executive compensation. The emphasis on corporate governance is particularly relevant to Korea given an earlier history of close state-business relations and the focus on corporate governance issues following the Asian financial crisis of the late 1990s (e.g., Kim and Kim, 2007). For example, large listed firms have since been required to establish an Audit Committee and an Appointment Committee under the board of directors comprised mainly of outside directors. As such, CSR evaluations in Korea understandably include surveys on the status of boards of directors and oversight systems.

\section{Ethical Responsibilities}

Ethical responsibilities refer to those responsibilities that go above and beyond obeying the letter of the law. In the context of African economies (Visser, 2006), ethical responsibilities refer to adopting voluntary codes of governance and ethics. Part of this stems from relatively weaker systems of governance in developing economies vis-à-vis more developed ones. In Korea, the importance of ethical responsibilities is woven into key issues such as fairness and employee satisfaction that go above and beyond the requirements of the law. These also include environmental considerations, where firms are evaluated based on improvements in green marketing and emissions levels in excess of legal requirements. In addition, the Sustinvest evaluation expands ethical responsibilities to include a 
focus on win-win cooperation, where growth strategies take into consideration both large firms and small-to medium-sized enterprises (SMEs). This item may represent one of the more unique features of CSR in Korea.

\section{Discretionary Responsibilities}

Discretionary responsibilities, or philanthropic responsibilities, involve being a "good citizen" with regards to Carroll's (1991) categorization, while Visser (2006) highlights their relatively important role in developing economies due to gaps in governance, limited public funds, and a history of social contribution. In such developing economies, philanthropic responsibilities encompass funds for corporate social as well as community projects. Discretionary responsibilities such as social contributions, community development programs, and local community investment are similar to conceptualizations by Carroll (1991) and Visser (2006). The importance of corporate philanthropy and trickle-down effects to society at large remains an important feature in Korea and is informed by past firm-society relations (e.g., Nam and Jun 2011). However, the role of philanthropy is not as central in the overall conceptualization of CSR in Korea as it is for developing economies as suggested by Visser (2006). In fact, there is a danger of public distrust of corporations that focus on economic and discretionary responsibilities while ignoring larger legal and ethical considerations.

\section{CONCLUSION}

While there have been arguments in the academic literature in support of the convergence of CSR conceptualizations and practice on a global level, there is a strong appreciation for understanding varieties of CSR in different national and regional contexts. This is of particular importance for firms looking to conduct operations overseas, as an understanding of local CSR conceptualizations and practices may help inform business strategy and lead to a swifter acceptance in the local community.

As such, this paper undertook an analysis of two prominent definitions of CSR in Korea as offered by the Korea Economic Justice Institute and Sustinvest Co., Ltd. One limitation of this paper was the difficulty in gauging the relative importance of economic, legal, ethical, and discretionary responsibilities. However, the two definitions offer meaningful insight into how the four responsibilities are conceptualized in the Korean context.

With regards to economic responsibilities, the importance of a firm's economic function is echoed in KEJI's index and is closer to the broader definition suggested by Visser (2006) rather than to the narrower one offered by Carroll (1991). Furthermore, economic responsibilities also include considerations of R\&D, pro- 
TABle 4. KoREA's VARIETY OF CSR In A COMPARATIVE CONTEXT

\begin{tabular}{|c|c|c|c|}
\hline Responsibility & $\begin{array}{l}\text { Anglo-American } \\
\text { Economies }\end{array}$ & African Economies & Korea \\
\hline Economic & $\begin{array}{l}\text { Primary importance of eco- } \\
\text { nomic responsibilities: tra- } \\
\text { ditionally refer to maximi- } \\
\text { zation of shareholder profit } \\
\text { (value) }\end{array}$ & $\begin{array}{l}\text { Economic responsibilities } \\
\text { important: emphasis on } \\
\text { economic responsibilities } \\
\text { placed on job creation, } \\
\text { paying taxes }\end{array}$ & $\begin{array}{l}\text { Economic responsibili- } \\
\text { ties important: constitute } \\
\text { R\&D efforts, operating } \\
\text { performance, economic } \\
\text { contribution (tax pay- } \\
\text { ments, productivity } \\
\text { growth, exports) }\end{array}$ \\
\hline Legal & $\begin{array}{l}\text { Importance of legal res- } \\
\text { ponsibilities after econo- } \\
\text { mic ones: refer to obeying } \\
\text { the letter of the law, or } \\
\text { playing the rules of the } \\
\text { game }\end{array}$ & $\begin{array}{l}\text { Legal responsibilities im- } \\
\text { portant, but philanthropic } \\
\text { (discretionary) responsi- } \\
\text { bilities emphasized: legal } \\
\text { responsibilities also tend to } \\
\text { focus on ensuring good } \\
\text { relations with government } \\
\text { officials, as opposed to } \\
\text { simply obeying the law }\end{array}$ & $\begin{array}{l}\text { Legal responsibilities } \\
\text { intertwined among key } \\
\text { issues: fair trade, supplier } \\
\text { relationships, workplace } \\
\text { safety, environmental } \\
\text { regulations; particular } \\
\text { importance with gover- } \\
\text { nance issues (shareholder } \\
\text { rights, transparency and } \\
\text { accountability, structure } \\
\text { of boards of directors, } \\
\text { and executive compen- } \\
\text { sation) }\end{array}$ \\
\hline Ethical & $\begin{array}{l}\text { Importance of ethical res- } \\
\text { ponsibilities follow econo- } \\
\text { mic and legal ones: being } \\
\text { ethical includes the obliga- } \\
\text { tion to do what is right, } \\
\text { just, and fair, as well as } \\
\text { avoiding harm }\end{array}$ & $\begin{array}{l}\text { Ethical responsibilities } \\
\text { least stressed among four: } \\
\text { refer to adopting voluntary } \\
\text { codes of governance and } \\
\text { ethics }\end{array}$ & $\begin{array}{l}\text { Ethical responsibilities } \\
\text { intertwined among key } \\
\text { issues: issues of fairness, } \\
\text { employee satisfaction, } \\
\text { environmental consi- } \\
\text { derations that go above } \\
\text { requirements of the law; } \\
\text { focus on win-win } \\
\text { cooperation unique to } \\
\text { Korean CSR }\end{array}$ \\
\hline Discretionary & $\begin{array}{l}\text { Least important of four } \\
\text { corporate social respon- } \\
\text { sibilities: involves being a } \\
\text { "good corporate citizen" } \\
\text { by contributing to the } \\
\text { community and making } \\
\text { efforts to improve quality } \\
\text { of life }\end{array}$ & $\begin{array}{l}\text { Importance of discretionary } \\
\text { responsibilities second } \\
\text { only to economic ones: } \\
\text { particularly given gaps in } \\
\text { governance, limited public } \\
\text { funds, and a history of } \\
\text { social contribution, phi- } \\
\text { lanthropic responsibilities } \\
\text { viewed with importance } \\
\text { and encompass funds for } \\
\text { corporate social/commu- } \\
\text { nity projects }\end{array}$ & $\begin{array}{l}\text { Importance of discre- } \\
\text { tionary responsibilities, } \\
\text { but do not trump legal } \\
\text { and ethical responsibi- } \\
\text { lities: meaningful role for } \\
\text { social contributions, } \\
\text { community development } \\
\text { programs, and community } \\
\text { investment }\end{array}$ \\
\hline Key Reference & Carroll (1991) & Visser (2006) & KEJI, Sustinvest \\
\hline
\end{tabular}

ductivity growth, and exports - a tribute to Korea's export-driven economy and its focus on the IT industry.

Legal and ethical responsibilities are interwoven in key issues reviewed in both KEJI's index and the evaluation matrix by Sustinvest. For legal responsibi- 
lities, Korean CSR includes issues of fair trade, supplier relationships, workplace safety, environmental regulations, and a particular emphasis on governance issues given the history of close state-firm ties and the Asian financial crisis of the late 1990s. Ethical responsibilities include issues of fairness, employee satisfaction, and environmental considerations that exceed the requirements of the law. One unique feature to Korean CSR is the focus on win-win cooperation, or on strategies of shared growth among large firms and SMEs.

Lastly, discretionary responsibilities have a meaningful place in Korean CSR with regards to social contributions, community development programs, and community investment. Simultaneously, these do not trump a firm's legal and ethical responsibilities and may be viewed with cynicism if other responsibilities remain unaddressed. Furthermore, the role of discretionary responsibilities is less central to Korean CSR than that of developing economies as argued by Visser (2006).

In highlighting key features of Korea's conceptualization of CSR, this paper provided an initial analysis of how CSR is understood and intended to be practiced in Korea. This should be of practical importance to both local and foreign firms who operate in Korea, as an understanding of expectations should help inform business strategy. In addition to providing clarity on the definition of CSR in Korea, this paper presented a preliminary comparison of Korean CSR and models for Anglo-American and developing economies, as suggested by Carroll (1991) and Visser (2006), respectively. However, future research may attempt to provide an even more authoritative understanding of CSR through a synthesis of additional definitions, particularly from firms and civil society, to provide further clarity on Korean CSR and its place in the wider global context. In addition, future research can supplement this analysis through a deeper comparative study of how CSR is understood in Korea vis-à-vis its Asian neighbors. This paper took it upon itself to place Korean conceptualizations of CSR within the existing framework of CSR as understood in the US versus African economies. A more interesting approach may be to understand similarities and differences in CSR between Korea and Japan, which have a shared (albeit contentious) history. Furthermore, such an approach may also explore similarities in national business systems with a focus on conglomerates, including those of Korea and Taiwan, both of which experienced rapid economic growth despite marked differences in their respective business systems.

\section{REFERENCES}

Barreto, Ilídio and Charles Baden-Fuller. 2006, To Conform or To Perform? Mimetic Behaviour, Legitimacy-Based Groups and Performance Consequences. Journal of Management Studies 43(7): 1559-1581.

Carroll, Archie. 1991. The Pyramid of Corporate Social Responsibility: Towards 
the Moral Management of Organizational Stakeholders. Business Horizons: $39-48$.

Chapple, Wendy and Jeremy Moon. 2005. Corporate Social Responsibility in Asia:

A Seven-Country Study of CSR Web Site Reporting. Business and Society 44(4): 415-441.

Chen, Stephen and Petra Bouvain. 2009. Is Corporate Responsibility Converging? A Comparison of Corporate Responsibility Reporting in the USA, UK, Australia, and Germany. Journal of Business Ethics 87(1): 299-317.

Choi, Jong-Seo, Young-Min Kwak, and Chongwoo Choe. 2010. Corporate Social Responsibility and Corporate Financial Performance: Evidence from Korea. Australian Journal of Management 35(3): 291-311.

Jamali, Dima and Ramez Mirshak. 2007. Corporate Social Responsibility (CSR): Theory and Practice in a Developing Country Context. Journal of Business Ethics 72: 243-262.

Jamali, Dima and Ben Neville. 2011. Convergence Versus Divergence of CSR in Developing Countries: An Embedded Multi-Layered Institutional Lens. Journal of Business Ethics 102(4): 599-621.

Jun, Hannah. 2013. Investing Well by Investing for Good?: Exploring the Motivations of Socially Responsible Investors. International Studies Review 14(1): 29-56.

Kim, E. Han and Woochan Kim. 2007. Corporate Governance in Korea: A Decade After the Financial Crisis. $U$ of Texas Law, Law and Econ Research Paper: 123.

Matten, Dirk and Jeremy Moon. 2008. Implicit and Explicit CSR: A Conceptual Framework for a Comparative Understanding of Corporate Social Responsibility. The Academy of Management Review 33(2): 404-424.

Misani, Nicola. 2010. The Convergence of Corporate Social Responsibility Practices. Management Research Review 33(7): 734-748.

Nam, Young-sook and Hannah Jun. 2011. The Shaping of Corporate Social Responsibility in Korea's Economic Development. Global Journal of Business, Management and Accounting 1(1): 10-20.

Oh, Won Yong, Young Kyun Chang, and Aleksey Martynov. 2011. The Effect of Ownership Structure on Corporate Social Responsibility: Empirical Evidence from Korea. Journal of Business Ethics 104(2): 283-297.

Visser, Wayne. 2006. Revisiting Carroll's CSR Pyramid: An African Perspective. pp. 29-55 in Corporate Citizenship in Developing Countries, edited by E. Pedersen and M. Huniche. The Copenhagen Centre: Copenhagen.

Visser, Wayne. 2008. Corporate Social Responsibility in Developing Countries. pp. 473-479 in The Oxford Handbook of Corporate Social Responsibility, edited by A. Crane, A. McWilliams, D. Matten, J. Moon and D. Siegel. Oxford: Oxford University Press. 